FACTA UNIVERSITATIS

Series: Physical Education and Sport Vol. 16, Nº 1, 2018, pp. 157 - 166

https://doi.org/10.22190/FUPES180507014I

Research article

\title{
EFFECTS OF TECHNICAL AND TACTICAL CHARACTERISTICS ON THE PERFORMANCE OF TABLE TENNIS PLAYERS
}

\author{
UDC 796.342 \\ 796.054
}

\section{Vladimir Ivanek ${ }^{1}$, Branko Đukić ${ }^{2}$, Branimir Mikić ${ }^{1}$, Miroslav Smajic ${ }^{3}$, Dragan Doder ${ }^{2}$}

${ }^{1}$ Faculty of Natural-Mathematical and Educational Sciences, Kinesiology Department, University of Mostar, Bosnia and Herzegovina

${ }^{2}$ Regional Institute of Sport and Sports Medicine, Novi Sad

${ }^{3}$ Faculty of Sport and Physical Education, University of Novi Sad, Serbia

\begin{abstract}
The aim of the research was to determine the effects of applied technical and tactical characteristics of table tennis players on their success in competitions. The representative sample consisted of 48 top senior table tennis players from Bosnia and Herzegovina, age 18 and 36, selected on the basis of a qualification tournament. The measuring instruments for this study included eight assessment tests for the table tennis players' technical and tactical characteristics and one test for assessing success in table tennis competitions. Technical and tactical characteristics of the participants were evaluated by five experts who analyzed the efficacy of technical and tactical characteristics of the players on a scale ranging from 1 to 5. The methods of processing the results included descriptive statistical procedures, the multiple correlation coefficient, the determinant coefficient and a multiple regression analysis. The results indicate that technical and tactical characteristics have a major impact on the player's performance and are essential for table tennis success. Based on the value of the regression coefficients and their significance, it may be concluded that the 5 variables statistically significantly contribute to the regression model are: the efficiency of the serve; the efficiency of preventing the attack of the opponent and preparation of the players' own attack; confidence when attacking across the table; the efficiency in the active defence and the efficiency of movement during the game. In the hierarchy of significance, the most important variables are the serve efficiency and efficiency of preventing the attack of an
\end{abstract}

Received May 05, 2017 / Accepted May 07, 2018

Corresponding author: Vladimir Ivanek

Faculty of Natural-Mathematical and Educational Sciences, Kinesiology Department,

University of Mostar, St. Matice Hrvatske n.n., 88000 Mostar, Bosnia and Herzegovina

Phone: +387 (0)36355-455• E-mail: v.ivanek@hotmail.com 


\begin{abstract}
opponent and preparation of the player's own attack. The efficiency of the serve allows an attacker to realize technical and tactical ideas and usually gain initiative in the game. By returning a serve we can prevent or at least make it harder for the opponent to attack again. A serve return can also allow us to take the initiative
\end{abstract}

Key words: Preparing own attack and preventing opponent's, the attack phase, the defence phase, elements of movement, ranking points.

\title{
INTRODUCTION
}

Knowledge about an athlete's physical, mental, and social characteristics in the initial phase, sport-shaping phase, and during specialization provides better guidance in training that can improve their development and lead to top-level results (Marković, Vučković, Sekulić \& Gadžić, 2015). The technical and tactical as well as motor requirements of the game are the results of the environment where the game takes place (Bratuša \& Dopsaj, 2015). Based on the structural complexity, table tennis as a sports game belongs to the poly-structural complex sports group dominated by open or semi-open movement structures that are performed in changing conditions.

Modern table tennis is characterized by segmental movement speed (limbs), explosive strength, speed of the punch with the optimal mastering (understanding) of ball rotation, which largely affects the performance of individual shots - topspin elements in the whole area of the game itself (Kondrič, Hudetz, Koščak, Slatinšek, \& Cerar, 2007). The speed and spin shots are two key elements of the modern sport played with a paddle. Speed of the balls is relatively visible to the audience, but the ball rotation or spin is not easy to detect (Chiu and Tu, 2006). Table tennis has progressed a lot through history, the game has become faster, and the points are faster while the shots are more powerful and precise. The complexity of certain technical and tactical elements and a large range of strokes made by players require maximum of physical and mental preparation (Fei et al, 2010).

In the modern training process of any sport activity, learning and practicing technical and tactical elements of the sport require a corresponding level of physical fitness of the player. During the development of physical abilities, we should not neglect those skills that are of great importance for that area of sport. To achieve top results in table tennis, it is necessary that the training process rely on the results of scientific research (Djukić, 2016).

The complexity of table tennis has led to the perfection of certain technical and tactical settings in the game, and thus the individual profiles of table tennis players have an important role in achieving the best results in this dynamic sport.

Specifically speaking, the studies dealing with the issue of motor skills, technical and tactical characteristics and successful performance exist, but as a rule these studies tested the difference between players with different quality levels (Toriola et al, 2004; Munivrana, 2011; Malagoli et al 2011; Bankosz, 2012). Therefore, it is interesting to determine which technical and tactical features are essential for success in table tennis.

Since in a structurally very complex sports game, such as the table tennis, performance of the players is determined by the level and structure of a large number of characteristics, skills and knowledge - the very tactics of table tennis that cannot be considered separately, not only from technical but also from anthropological and specific fitness capacities of the player on which the tactics directly rest. All of these skills, characteristics and knowledge 
together influence the overall performance of athletes or, to different degrees, achieving the results, being the final measure of the overall athlete's efficiency (Ivanek, 2015).

For the successful implementation of tactics, it is important to know the characteristics of your opponent's play, as well as knowledge of the effectiveness of individual technical and tactical skills in a particular competitive situation (Ivanek, 2015).

The main goal of the research is to determine the impact of technical and tactical characteristics on the table tennis players' performance i.e. a set of technical and tactical characteristics as predictor (independent) variables on the one hand and the criterion variable of the player's position in the ranking table on the other hand.

\section{METHODS}

\section{Sample of participants}

The representative sample consisted of 48 top seniors from Bosnia and Herzegovina, age 18-36, selected based on a qualifying tournament of all registered table tennis players. All of the participants were introduced to the test methods and they provided written consent for testing. The research was carried out in accordance with the Declaration of Helsinki and it was approved by the Ethics Committee of the Faculty of NaturalMathematical and Educational Sciences, Kinesiology Department, University of Mostar.

\section{Sample of tests}

Tests for the assessment of technical and tactical characteristics of the players

The tests were selected based on the results of current research in the field of table tennis (Djokić, 2001; Munivrana, 2011), which have been dedicated to solving the technical and tactical demands of the game.

To assess the technical and tactical characteristics of the players we applied the following parameters:

- Phase of preventing the attack of an opponent and preparation of the player's own attack. (The opponent tries to prevent taking initiatives in points and tries to achieve his/her own offensive advantage).

1. (EFSERV) - Serveefficiency

2. (EFOPIO) - Efficiency of preventing the attack of an opponent and preparation of the player's own attack.

- Attack phase (player makes the move and takes the initiative in earning points)

1. (SIEFNA) - Confidence and efficiency during the attacking patterns of play over the table

2. (SIEFPU) - Confidence and efficiency during the first attack

3. (EFKONA) - Efficiency during a continuous activity of attacking

- Defence phase (stage of the game when the opponent takes the initiative in earning points)

1. (EFPAOB) - Passive defence efficiency

2. (EFAOBR) - Active defence efficiency 
- Elements of moving (all types of movement during the game)

1. (EFKREI) - Efficiency of moving during the game

Parameters for the assessment of the player's performance

For the assessment of the player's performance we used the parameter:

- (BODRNG) - number of points (ranking).

\section{Description of the measuring process}

In this study, the space of technical and tactical characteristics of a table tennis player is represented by eight (8) parameters that perform the operationalisation of technical and tactical characteristics space (serve efficiency, efficiency of preventing the attack of an opponent and preparation of the player's own attack, confidence and efficiency during the attacking patterns of play over the table, confidence and efficiency during the first attack, efficiency during a continuous activity of attacking, passive defence efficiency, active defence efficiency, efficiency of moving during the game).

The performance of a player is represented by one parameter (the number of points or ranking).

The technical and tactical characteristics of the participants were evaluated by five (5) experts and with 5 ranking data (1-bad, 2-enough, 3-good, 4-very good, 5-excellent). Each assessed technical and tactical efficiency of a player was ranked on a scale ranging from 1 to 5, wherein the higher rank denoted better technical and tactical characteristics of the player.

\section{Data processing methods}

Descriptive indicators of variables for assessing the technical and tactical characteristics of table tennis players were applied. The multiple correlation coefficient and coefficient of determination for the model that assesses the table tennis players' position in the rankings were calculated. A multiple regression analysis was applied (Bartlett, 1947), in order to determine the effects of predictor variables (technical and tactical characteristics) on the criterion variable (performance of a table tennis player). A significance level of $95 \%$ was used. Processing was performed by using the SPSS package ver. 17.0.

\section{RESULTS}

Based on the regression analysis that was applied, it was determined that all the parameters from a set of technical and tactical characteristics significantly correlate with the position of the participant in the ranking, while technical and tactical characteristics among themselves correlate moderately (Table 1). The exceptions are the following parameters: (SIEFNA) - Confidence and efficiency during the attacking patterns of play over the table (SIEFPU) - Confidence and efficiency during the first attack which are in high correlation $(r=.77)$. Bearing in mind that the said parameters shared more than $50 \%$ of the common variability, the parameter (SIEFPU) - Confidence and efficiency during the first attack has been removed, the safety and efficacy of the first input (SIEFPU), 
because it has a somewhat lower degree of correlation with the criterion $(\Delta \rho=.03)$, so that 7 (seven) parameters of technical and tactical characteristics of table tennis players were applied in the further analysis.

Table 1 Descriptors and indicators of the multicollinearity of predictor variables included in the regression model

\begin{tabular}{lcccc}
\hline Parameters & $\mathrm{M}$ & $\sigma$ & $\mathrm{N}$ & $\mathrm{VIF} * *$ \\
\hline EFSERV* & 2.5625 & .88260 & 48 & 2.47 \\
EFOPIO & 2.7500 & .73975 & 48 & 3.25 \\
SIEFNA & 3.0208 & .85675 & 48 & 2.93 \\
EFKONA & 3.0333 & .89093 & 48 & 1.84 \\
EFPAOB & 2.9250 & .86603 & 48 & 1.88 \\
EFAOBR & 2.7750 & .76478 & 48 & 2.09 \\
EFKREI & 2.9417 & .91229 & 48 & 1.77 \\
\hline
\end{tabular}

Legend:(EFSERV) Serve efficiency; (EFOPIO): Efficiency of preventing the attack of an opponent and preparation of the player's own attack;(SIEFNA): Confidence and efficiency during the attacking patterns of play over the table; (EFKONA): Efficiency during a continuous activity of attacking; (EFPAOB): Passive defence efficiency; $(E F A O B R)$ : Active defence efficiency; (EFKREI): Efficiency of moving during the game; $(B O D R N G)$ : number of points (ranking); VIF - variance inflation factor

Low values of the variance inflation factor (VIF) indicate the applicability of the selected parameters as predictors.

Table 2 Multiple correlation coefficient and coefficient of determination for the position of table tennis players in the rankings estimating model.

\begin{tabular}{ccccc}
\hline Model & $\mathrm{R}$ & $\mathrm{R}^{2}$ & Corrected $\mathrm{R}^{2}$ & Standard error \\
\hline 1 & .80 & .64 & .57 & 9.09 \\
\hline
\end{tabular}

Based on the prediction parameters that are included in the regression model: (EFSERV) Serve efficiency; (EFOPIO): Efficiency of preventing the attack of an opponent and preparation of the player's own attack;(SIEFNA): Confidence and efficiency during the attacking patterns of play across the table; (EFKONA): Efficiency during a continuous activity of attacking; (EFPAOB): Passive defence efficiency; (EFAOBR): Active defence efficiency; (EFKREI): Efficiency of moving during the game, one regression function is set aside. The multiple correlation coefficient amounts to $\mathrm{R}=$ .80 , which means that with the inclusion of the parameters from the set of technical and tactical characteristics that are significant to the criterion parameter we can explain about $64 \%$ of variance regarding the table tennis players performance expressed through player position in the rankings (Table 2).

Table 3 Assessment of the significance of the regression model in predicting the position of the participants in the rankings

\begin{tabular}{llcrrrc}
\hline & Model & Amount of the squares & Df & Average square & F & $\mathrm{p}$ \\
\hline 1 & Regression & 5901.709 & 7 & 843.101 & 10.188 & .000 \\
Residual & 3310.291 & 40 & 82.757 & & \\
& Total & 9212.000 & 47 & & & \\
\hline
\end{tabular}


Assessment of the regression model significance is effected through the $\mathrm{F}$ relation. The calculated regression function is statistically significant $F=18.10 \mathrm{p}<0.01$ (Table 3) and in order to facilitate the perception of the obtained results, contributions of individual parameters from the set of technical and tactical characteristics of those regression model are shown (Table 4).

Table 4 Partial contribution of the parameters to the regression model

\begin{tabular}{lllllll}
\hline \multicolumn{1}{c}{ Model } & $\mathrm{B}$ & $\mathrm{B}_{\mathrm{se}}$ & $\beta$ & $\mathrm{t}$ & $\mathrm{p}$ \\
\cline { 1 - 5 } 1 Constant & & 70.31 & 6.35 & & 11.06 & .000 \\
\cline { 1 - 5 } EFSERV & -8.36 & 2.76 & -.62 & -4.13 & .001 \\
EFOPIO & -8.19 & 2.63 & -.57 & -3.36 & .002 \\
SIEFNA & -7.83 & 2.65 & -.48 & -2.95 & .004 \\
EFKONA & -2.39 & 2.02 & -.15 & -1.18 & .245 \\
EFPAOB & -1.33 & 2.10 & -.08 & -.63 & .528 \\
EFAOBR & 7.92 & 2.51 & .46 & 2.84 & .005 \\
EFKREI & -8.06 & 2.33 & -.50 & -3.09 & .004 \\
\hline
\end{tabular}

Based on the value of standard regression coefficients and their significance (Table 4) it can be concluded that the 5 parameters significantly contribute to the regression model: (EFSERV) - serve efficiency; (EFOPIO) - efficiency of preventing the attack of an opponent and preparation of the player's own attack (SIEFNA) - Confidence and efficiency during the attacking patterns of play across the table; (EFAOBR)- Active defence efficiency and (EFKREI) - Efficiency of moving during the game.

The downward trend of positions in the ranking of participants is noticeable, and it can be concluded that with a more favourable rating (higher ranking) on the scale, serve efficiency (EFSERV) $(\beta=-.62)$, confidence and efficiency during the attacking patterns of play over the table (SIEFNA) $(\beta=-$. 48), efficiency of preventing the attack of an opponent and preparation of the player's own attack (EFOPIO) $(\beta=-.57)$, active defence efficiency (EFAOBR) $(\beta=-.46)$ and the efficiency of moving during the game (EFKREI) $(\beta=-.50)$, they will have a better (lower rank) in the ranking.

There is a linear relationship between the set of technical and tactical characteristics as predictors (independent) parameters on the one hand, and the criterion parameter of the players position in the rankings on the other hand. The obtained multiple correlation coefficient is statistically significant and amounts to $\mathrm{R}=.80$, which indicates that about $57 \%$ of the variance in terms of parameter results regarding position of the players in the ranking can be explained with the help of the assessment of the participants' technical and tactical characteristics obtained by expert assessment.

We can conclude that in a hierarchy of significance, the most important positioned parameters are: serve efficiency and efficiency of preventing the attack of an opponent and preparation of the player's own attack (variables that belong to the stage of the game where the player prepares his/her own attack and prevent the attack of the opponent). The serve efficiency allows an attacker realisation of technical and tactical ideas and usually taking the initiative in the game. By receiving a serve, we can prevent or at least make it harder for him/her to perform the next offensive action or we can take the initiative in the game. 
The vast majority of points in modern table tennis end after 2-3 shift of shots, which means that the serve and reception of the serve usually make up from one third to as much as one half of all shots in an average game. Nevertheless, vast majority of points ends with the decision made immediately after the end of the serve and reception of serve, which means that the quality of serve or receiving service directly influences the outcome of the points.

\section{DISCUSSION}

For the successful implementation of tactics, it is important to know the characteristics of your opponent's play, as well as knowledge of the effectiveness of individual technical and tactical skills in a particular situation (Ivanek, 2015).

As might be expected, the technical and tactical performance is highly influenced by the performance of players (Zhang et al, 2014). Specifically, based on the previously discussed analysis, but on the professional experience in table tennis as well, it was clear that the technical and tactical efficiency was a basis for the overall performance of table tennis. In other words, technical and tactical assumptions and requirements are very high and directly determine the final performance (Munivrana, 2011). If we would try to make a kind of hierarchical structure of the importance of certain parameters for success in table tennis, the game would look as follows:

Service efficiency (EFSERV) $(\beta=-.62)$,

Efficiency of preventing the attack of an opponent and preparation of the player's own attack (EFOPIO) $(\beta=-.57)$

Efficiency of moving during the game (EFKREI) $(\beta=-.50)$,

Confidence and efficiency during the attacking patterns of play over the table; (SIEFNA) $(\beta=-.48)$,

Active defence efficiency (EFAOBR) $(\beta=-.46)$,

However, this hierarchy should be interpreted with some caution, because as you can see, a very small numerical differences in standardized coefficients of the partial contributions of individual parameters is in question.

Generally, the efficiency of the serve is extremely important in table tennis. Specifically, the efficient serve, above all, enables a player to win the point directly, or on the other hand, the efficient serve enables the player a better position for winning points in the match.

The second parameter of importance is the efficiency of preventing the attack of an opponent and preparation of the player's own attack.

In table tennis, tactics applied by each individual player depend directly on the size of his morphological characteristics, motor skills and the quantity of technical and tactical knowledge. However, as the table tennis players compete, the applied tactic depends on the structure of the opponent's game (Ivanek, 2015).

Therefore, it is important to know the characteristics of your opponent's game for each successful application of tactics, as well as to have knowledge of the effectiveness of individual technical and tactical skills in a particular situation of the match. In other words, it is necessary to know the effects that each element will cause and what its use will cause the opponent. Table tennis basic techniques, in any of their variations, are used 
at the same time as a tactical elements through the main tactic agents, such as: speed of the ball, rotation of the ball, placing the ball (Malagoli et al., 2013). The basic tactical means are combined in a great number of different varieties which build a complex game plan at any point of the table tennis match, although the overall tactics of course includes a number of other tactical actions such as preparation for the match, analysing opponents, directing the game towards the weak points of the opponent, taking a "time-out", and so on. (Munivrana, 2011).

From the above mentioned, it is clear that the technical and tactical elements applied in this paper have the greatest importance in explaining the results of a table tennis player (Komijima et al, 2010). Specifically, they are directly related for achieving good results, while all other factors (morphological, motor, psychological, etc.) are in the background of the technical and tactical performance which produces a result.

The results of this study are consistent with the results obtained in other studies, which analysed similarities and differences in the styles of play and their efficiency regarding the best Bulgarian and global table tennis players (Galina, 1992). The mentioned studies also analysed and assessed performance during matches and the placement of the player on the ITTF ranking table (Djokić, 2001), explored the impact of technical and tactical elements on the performance at the World Table Tennis Cup for Women - Singapore (Zhifeng \& Wei, 2002), determined the structure, role and hierarchical character of the technical and tactical elements in table tennis (Munivrana, 2011), determined that the players through the training can develop their skills evenly in the three phases (the attack upon the serve $69 \%$, attack as a response to the serve - $49 \%$ - reception of the serve and an attack upon defense against attacks $-46 \%$ ) or a special technique can be developed for each of the stages ( $\mathrm{Li}, 1996)$.

\section{CONCLUSION}

Technical and tactical features significantly affect the player's performance. Table tennis as a sports game belongs to the group of polystructural acyclic sports and thus it is clear that the technical and tactical efficiency is essential for the performance of the player.

Evidently, the players included in this study, during the training process and the preparation, paid more attention to practicing simple technical and tactical structures, leaving at the same time a number of the other tactical actions such as the preparation for a specific competition, analysing the game of the opponents, directing the play towards weak points of the opponent, etc.

This is probably caused by the inadequate professional support by trainers and conditions of the training processes in terms of the clubs that exist in Bosnia and Herzegovina.

Technical and tactical efficiency represents the very essence of the player's performance. In other words, technical and tactical assumptions and requirements are very high and directly determine the final performance during a competition. 


\section{REFERENCES}

Bankosz, Z. (2012). The kinesthetic differentiation ability of the table tennis players. Human movement, 13(1), $16-22$.

Bartlett, M.S. (1947). Multivariate analysis. Journal of Royal Statistical Society B, 9, 176-197.

Bratuša, Z., \& Dopsaj, M. (2016). The effect of various leg kick techniques on the vertical jump among water polo players. Facta Universitatis, Series: Physical Education and Sport, 419-430.

Chiu, Y. H., \& Tu, J. H., (2006). The measuring method for the spin axis and the rate of the rotational ball. Journal of Physical Education in Higher Education, 8(3), 139-147.

Djokić, Z. (2001). Structure of competitors activities of top table tennis players. Table tennis Sciences, $4 \& 5$, 74-91.

Djukić, B. (2016). Dijagnostika i razvoj funkcionalnih sposobnosti stonotenisera (Diagnostics and development of functional capabilities of table tennis players). Novi Sad. Aktuelno u praksi. Časopis za naučno-stručna pitanja u segmentu sporta, 26, 5-13.

Fei, Y., Ushiyama, Y., Jie, L., H., Lizuka, S., \& Komijama, K. (2010.). Analysis of the ball fall point in table tennis game. International Journal of Table Tennis Sciences, 6, 131-136.

Galina, V. B. (1992). Competitive activity of the best table tennis players. International Journal of Table Tennis Sciences, 1, 135-140.

Ivanek, V. (2015). Utjecaj nekih antropoloških dimenzija i tehničko-taktičkih karakteristika na natjecateljsku uspješnost $u$ stolnom tenisu (The influence of some anthropological dimensions and technical-tactical characteristics on the competitive performance of table tennis). Doktorska disertacija. Mostar. Fakultet prirodoslovno-matematičkih i odgojnih znanosti Sveučilišta u Mostaru.

Ivanek, V., Mikić, B., Ćorluka, M., Brekalo, M., \& Čerkez, I. (2015). Influence of Motor Abilities on Competitive Efficacy in Table Tennis. Sports Science and Health 5(1), 55-63.

Komijima, K., Ushiyama, Y., Zhang, H. Y., Fei, Y., \& Izuka, S. (2010). The examination for evaluating skills during the rally of the Table Tennis game. International Journal of Table Tennis Sciences, 6, 127-130.

Kondrič, M., Hudetz, R., Koščak, J., Slatinšek, U., \& Cerar, K. (2007). Research regarding possibilities of marking the ball in order to make spin visible. U M. Kondrič, \& G. Furjan Mandić (Eds.), Proceedings book of The $1^{\text {Oth }}$ Anniversary ITTF Sports Science Congress (str. 120 - 122). Zagreb: University of Zagreb, Faculty of kinesiology; Croatian Table Tennis Association; International Table Tennis Federation.

Li, Z. (1996). Technical index of an Olyimpic table tennis gold medal winner. International Journal of Table Tennis Sciences, 3, 151-153.

Malagoli, L.I., Rocco, M., \& Franco, M. (2011). Reliability of selected table tennis performance indicators. International Journal of Table Tennis Sciences, 7, 62-65.

Malagoli, L.I., Rocco, Di M., \& Franco, M. (2013). Technical and tactical performance of top-class senior, junior and cadet table tennis players. International Journal of Table Tennis Sciences, 8, 80-85.

Marković, S., Vučković, I., Sekulić, Ž., \& Gadžić, A. (2016). Physical performance modeling among young basketball and handball players. Facta Universitatis, Series: Physical Education and Sport, 263-273.

Munivrana, G. (2011). Strukturna analiza tehničko-taktičkih elemenata stolnoteniske igre (Structural analysis of technical-tactical elements of table games). Doktorska disertacija. Zagreb: Sveučilište u Zagrebu, Kineziološki fakultet.

Toriola, A. L., Toriola, O. M. \& Iqubokwe, N. U. (2004). Validity of specific motor skills in predicting Table Tennis performance in novice players. Perceptual and Motor Skills, 98(2), 584-586.

Zhang, H., Liu, W., Hu, J. J., \& Liu, R. Z. (2014). Evaluationof elite table tennis players' technique effectiveness. Journal of sports sciences, 32(1), 70-77.

Zhifeng, Q., \& Wei, X. (2002). Impact on technical tactical capabilities performance Table Tennis World cup Shanghai. International Journal of Sports Science and Enginering, 1(3). 


\section{EFEKTI TEHNIČKO-TAKTIČKIH KARAKTERISTIKA NA UČINAK STONOTENISERA}

Cilj istraživanja bio je da se utvrde efekti primenjenih tehničkih i taktičkih karakteristika stonotenisera na njihov uspeh u takmičenjima. Uzorak ispitanika sastojao se od 48 vodećih viših stonotenisera iz Bosne i Hercegovine, starosti 18 i 36 godina, odabranih na osnovu kvalifikacija na turnirima. Merni instrumenti za ovu studiju obuhvatao je osam testova za procenu tehničkih i taktičkih karakteristika stonotenisera i jedan test za procenu uspeha na takmičenjima. Tehničke i taktičke karakteristike učesnika je procenilo petoro eksperata koji su analizirali efikasnost tehničko-taktičkih karakteristika igrača na skali od 1 do 5. Postupci za obradu rezultata podrazumevali su deskriptivne statističke procedure, koeficijent višestruke korelacije, koeficijent determinanta i višestruka regresiona analiza. Rezultati ukazuju na to da tehničke i taktičke karakteristike imaju veliki uticaj na učinak stonotenisera $i$ da su od suštinskog značaja za uspeh u stonom tenisu. Na osnovu vrednosti koeficijenata regresije $i$ njihovog značaja, može se zaključiti da 5 varijabli statistički značajno doprinose regresionom modelu, uključujući: efikasnost prilikom servisa; efikasnost u sprečavanju napada na protivnika i pripremu sopstvenog napada; samopouzdanje prilikom napada preko stola; efikasnost $u$ aktivnoj odbrani $i$ efikasnost pokreta tokom igre. $U$ hijerarhijskom smislu, najvažniji varijable su efikasnost servisa i efikasnost pri sprečavanju napada protivnika i pripremi igrača za vlastiti napad. Efikasnost pri servisu omogućava napadaču da ostvari tehničke i taktičke ideje i obično dobije inicijativu u utakmici. Uz pomoć povratnog servisa možemo sprečiti ili barem otežati protivniku da ponovo napadne. Odovor na servis takođe može igraču dati inicijativu tokom igre.

Ključne reči: Priprema sopstvenog napada i sprečavanja napada protivnika, faza napada, faza odbrane, elementi pokreta, poeni za rangiranje. 